\title{
Views of Teachers on Innovations Done in Education and Instruction
}

\author{
S. Gülşah YILDIRIM ${ }^{* *}$ \\ Nuriye SARIOĞLAN****
}

\author{
S. Serap AVGIN ${ }^{* * * *}$ \\ Merve KARATAŞ*****
}

Received: 27 November 2014

Accepted: 26 June 2015

\begin{abstract}
The purpose of the study is to explore teachers' views on recent innovations done in education and instruction. 25 teachers were asked semi-structured questions in this study and responses were descriptively analyzed. Some of the research findings indicated that most of the teachers agreed that student-centered approaches were more effective in achievement than conventional ones, and the enforcement of teachers is necessarily related to students' attendance. Other views were related to school readiness of 5th graders. According to findings, subject teachers were not stated to cause any effect on 5th graders. Starting school earlier was stated to affect them adversely Generally, the teachers agreed that changes in education is necessary to train qualified individuals for the World, which is constantly changing and evolving.
\end{abstract}

Keywords: Innovations in education, constructivist approach, dress code in education, student.

\section{Extended Abstract}

Purpose and Significance: The aim of this study is to explore teacher' views on recent innovations done in education and instruction. Teachers are practitioners of innovation in education. If they have positive views about this innovation, so they become more workable. Therefore, the results of this study can be a guiding light for decision makers.

Methods: In this study, 25 teachers were asked semi-structured questions and responses were descriptively analyzed. Themes were created according to codes.

Results: Teachers agreed that viewpoint to approach, knowledge about topic and effect on students of teachers shouldn't be ignored and student-centred approaches are effective in student achievement. According to findings of study, most of teachers said that there are several methods of student assessment and students should be evaluated as a whole using these methods together. Teachers reached consensus on that if existing

\footnotetext{
** Corresponding Author: Arş. Gör., Uludağ Üniversitesi, Bursa, Turkey, sevda_yil@mynet.com

*** Doç. Dr., Sütçü İmam Üniversitesi, Kahramanmaraş, serapavgin@ hotmail.com

**** Sütçü İmam Üniversitesi, Kahramanmaraş, Türkiye

***** Sütçü İmam Üniversitesi, Kahramanmaraş, Türkiye
}

\section{Citation Information}

Yıldırım, S. G., Avgın, S. S., Sarıŏlan, N., \& Karataş, M. (2016). Eğitim ve öğretimde gerçekleştirilen yenilikler üzerine öğretmen görüşleri. Kuramsal Eğitimbilim Dergisi [Journal of Theoretical Educational Science], 9(3), 461-475. 
methods use in this way, they can be sufficient. While most of teachers think that free uniform application adversely affects children of low-income families, as for some of them considers that free uniform application becomes effective the emergence of free thought and ideas. Very few teachers defend is that teachers shouldn't be any suppressive effect on students concerning sanction of teachers related to students' class attendance. A large majority of teachers have approved entering subject teachers to the fifth grade. According to findings in the matter of effect of be lowered of school starting age on students' school success and psychological states, most of teachers are welcoming negative to start school at an early age.

Discussion and Conclusion: According to results of interview with teachers, it is communicable that teachers aren't against innovations. However, that teachers haven't arrived at a consensus on some questions shows that reforms in education haven't been adopted by everyone exactly. Rapidly globalizing world, and brings with it many innovations. These innovations and changes affect all individuals. Education is directly related to human breeding individuals can adapt better to the changing world and to be able to meet the desired attributes have been introduced some innovations into educational practice. One of these innovations is the student-centred approach. The juncture of the teachers on the subject, the student-centred teaching approach based on the constructivist approach, taking into consideration instead of transferring information to students, students' knowledge of the intended configuration is that a mentally or socially. In addition, applications that have a positive impact on the students, but students should not overlook the impact on the teachers has been emphasized. The fundamental aim of educational children's happiness, autonomy and their capacity to do business is to develop independent. In line with this dress regulations in education in relation to the education system and getting away from monotype are becoming more sensitive to social demands. Free clothing negative thinking about the practice of teachers, this situation uncovering the economic differences between rich and poor will trigger the separation will occur in the direction of class difference and the difference is they are anxious. As well as their attention away from the academic process and will be more comfortable in the school environment reflects the ideologies of individuals that would have added their thoughts. A group of teachers to uncover the economic differences in the application of free clothes is not a prerequisite, students, etc. it also with shoes and handbags. Free clothing through the application of freer, self-reliant individuals will grow and dress for success cannot be measured is indicated. In the same way, Üstün and Çeğindir (2006) according to the findings of his study form the majority of the mothers stated that they are not satisfied with the user. For every perspective, every thought is different and, of course, different answers are, but our ancestors, has said, "The tree when wet bends" adage is appropriate aspect of the regulation seems to be advantageous are a prospective light of hope forms. 


\title{
Eğitim ve Öğretimde Gerçekleştirilen Yenilikler Üzerine Öğretmen Görüşleri
}

\author{
S. Gülşah Yıldırım** \\ S. Serap Avgın ${ }^{* * *}$ \\ Nuriye Sarığlan $* * * *$ \\ Merve Karataş*****
}

Makale Gönderme Tarihi: 27 Kasım 2014

Makale Kabul Tarihi: 26 Haziran 2015

\begin{abstract}
ÖZ: Bu çalışmanın amacı, eğitim ve öğretimde gerçekleştirilen son yenilikler üzerine öğretmenlerin görüşlerini ortaya çıkarmaktır. Bu çalışmada, 25 öğretmene yarı yapılandırılmış olarak hazırlanan sorular sorulmuş ve betimsel olarak analiz edilmiştir. Araştırma bulgularının bazılarına bakıldığında, öğretmenlerin çoğu öğrenci merkezli yaklaşımların öğrencinin başarısında geleneksel yaklaşımlardan çok daha etkili olduğunu, öğrencilerin derse devamlılığında öğretmen yaptırımının gerekli olduğunu kabul etmektedirler. Diğer görüşler, 5. sınıf öğrencilerinin hazırbulunuşluğu ile ilgilidir. Bulgulara göre, branş öğretmenlerinin, 5. sınıf üzerinde herhangi bir etkiye sebep olmamaktadırlar. Okula erken yaşta başlamanın olumsuz olarak onları etkilediği belirtilmiştir. Genel olarak öğretmenler, sürekli değişen ve gelişen dünyaya nitelikli bireyler yetiştirmek için eğitimde değişimlerin gerekli olduğu konusunda birleşmektedirler.
\end{abstract}

Anahtar kelimeler: Eğitimde yenilikler, yapılandırmacı yaklaşım, eğitimde kılık kıyafet, öğrenci.

\section{Giriş}

Hayatın her evresinde yer etmiş olan eğitim, belirli bir sistem üzerine kurulmuş politik, sosyal, bireysel ve kültürel boyutları içine alan bir süreçtir. Bu nedenle eğitim üzerine birçok tanım yapılmış, en ideal eğitim modeli yaratmak amacıyla sürekli yenileşme ve değişme çabasına girişilmiştir. En genel geçer hâliyle eğitim, bireyin kendi yaşantısı yoluyla ve kasitlı olarak istendik davranış değiştirme süreci olarak tanımlanmaktadır (Ertürk, 1984, s. 4). Öğretim ise, tüm öğretme faaliyetlerinin önceden belirlenmiş hedefler doğrultusunda planlı ve kontrollü olarak düzenlenmesi ve yürütülmesidir (Fidan, 1996).

Eğitim ve öğretim faaliyetlerinden en yüksek verimi elde etmek ve ideal düzeye ulaşmak amacıyla ana şekilleri ve amaçları değişmemekle beraber, eğitim sisteminde birçok yenileşme çabası görülmektedir. Bu yenileşme hareketlerinin anlaşıllır olabilmesi için geleneksel eğitim modellerini kavramak ve eğitim sisteminin tarihsel gelişimine vakıf olmak gerekmektedir.

Türk eğitim sisteminin tarihine bakıldığında, Osmanlı da eğitimin temel amacının 'iyi bir dindar kişi yetiştirmek' olduğu görülmektedir. Cumhuriyet dönemi eğitim sisteminin amaçlarıyla farklılık gösteren bu sistemde eğitim, altı yaşın sonunda başlamaktadır. Eğitim kurumu ise karakteristik olarak medreselerdir. 18. yüzyılda eğitimde Avrupa'dan geri kalındığı düşüncesiyle Osmanlı Devleti, eğitimde yenilikler yapmaya başlamıştır. Genellikle askeri alanda yenileşme çabalarına destek amacıyla askeri okullar ve tersaneler açılmaya başlanmış ancak sivil eğitimle ilgili ciddi reformlar

\footnotetext{
** Arş. Gör., Uludağ Üniversitesi, Bursa, Turkey, sevda_yil@ mynet.com

*** Doç. Dr., Sütçü İmam Üniversitesi, Kahramanmaraş, Türkiye, serapavgin @hotmail.com

**** Sütçü İmam Üniversitesi, Kahramanmaraş, Türkiye

****** Sütçü İmam Üniversitesi, Kahramanmaraş, Türkiye
} 
19. yüzyılda yapılmaya çalışılmıştır. 1824 yılında II. Mahmut'un ilköğretimi zorunlu hâle getirmesiyle halk arasında eğitim ve öğretim yaygınlaştırılmaya çalışılsa da bu reform İstanbul ili dışına pek fazla yayılmamıştır. II. Abdülhamit zamanında, eski ve yeni usul tartışmaları çıkmıştır. Ancak ilköğretimin paralı olması sebebiyle yapılmaya çalışılan yenilikler yeterince etkin olmamıştır. II. Meşrutiyetin ilanı ile birlikte ilköğretimin zorunlu ve parasız olması herkesçe kabul edilmiştir.

19. yüzyılda Osmanlı Devleti'nde dört tip birbirinden farklı eğitim sistemi hüküm sürmektedir: mektep-medrese sistemi, Batı örneğine göre oluşturulan Osmanlı eğitim sistemi, yabancı okulların eğitim sistemi ve azınlıkların okul sistemi. Farklılık gösteren ve birbirine uyumsuz bu eğitim sistemlerinin birleştirilmesi ve belli bir düzene oturtulması 20. yüzyılda gerçekleştirilebilmiştir. Cumhuriyetin ilanından sonra eğitimdeki ayrılıkları çözmek amacıyla 1924 yılında 'Tevhid-i Tedrisat Kanunu' çıkarılmış, medreseler kapatılmış, eğitim-öğretim faaliyetleri tek bir merkeze bağlanmıştır (Ergün, 2013).

Türkiye Cumhuriyeti bu tarihten itibaren eğitim-öğretim seviyesinin arttırılması için birçok müfredat değişikliğine gitmiş (1924, 1926, 1936, 1948, 1968, 1997, 2005), çağdaş medeniyet seviyelerine ulaşmak amacıyla zorunlu eğitim yaşından kılık kıyafete, değerlendirme yöntemlerinin modernleşmesine kadar çeşitli alanlarda yenilikler gerçekleştirmiştir. Türkiye Cumhuriyeti’nde eğitim-öğretim faaliyetleri Milli Eğitim Bakanlığı (MEB) tarafindan yürütülmekte, yabancı okullarda dâhil olmak üzere tüm okulların işlevleri devlete bağlı olarak sürdürülmektedir. Bu çalışmanın amacı da son dönem yapılan yeniliklere yönelik öğretmen görüşlerinin ne olduğunun ortaya çıkarılmasıdır. Görüşler 'öğrenci merkezli yaklaşımların öğrenci başarısına etkisi', 'öğrenci değerlendirilmesinde mevcut yöntemlerin yeterliliği', 'serbest kıyafet uygulamasının öğrencilerin kişilik ve sosyal yönden gelişimine, akademik başarısına etkisi', 'öğrencilerin derse devam durumu ile ilgili öğretmen yaptırımı', '5. sınıf öğrencilerinin hazırbulunuşluluğu açısından branş öğretmenlerin derse girmesi', 'okula başlama yaşının düşürülmesi’ maddeleri üzerinden alınmıştır.

\section{Öğrenci Merkezli Yaklaşımlar}

Her alanda sürekli değişimlerin ve yeniliklerin meydana geldiği dünyada, hiç kuşkusuz eğitim alanında da birtakım yenilikler ve bunun doğal sonucu olarak dönüşümler yaşanmaktadır. Hatta eğitimde meydana gelen bu değişimler; ülkelerin eğitim politikalarını etkilemekte ve eğitim politikalarının sürekli güncellenmesi zorunlu hale gelmektedir (Özden, 2000, s. 17). 2005 y1lından itibaren eğitimin sistemimizin odaklandığı yapılandırmacı yaklaşım ile eğitim alanında meydana gelen gelişmeler doğrultusunda öğretmen, öğrenci, veli, okul yöneticisi, eğitim programları, öğrenme yaşantıları, ölçme ve değerlendirme farklı boyutlar kazanmıştır (Çınar, Teyfur \& Teyfur, 2006). Yapılandırmacı yaklaşım çerçevesinde şekillendirilen yeni programda kendini ifade eden, iletişim kuran, işbirliği yapan, girişimci ve sorun çözen, bilimsel düşünen, anlayan, araştıran, inceleyen, eleştiren, sorgulayan ve yorumlayan, bilgi ve iletişim teknolojilerini kullanan, bilgi üreten ve geleceğine yön veren” bireyler yetiştirmek amaçlanmıştır (Milli Eğitim Bakanlığı [MEB], 2005). Bu yaklaşımda öğretme değil, 
öğrenme ön plândadır ve öğrenme süreçlerine odaklanılmıştır (Özden, 2005; Titiz, 2005). Bu sebeple bu yaklaşımda, öğretmenin de rolü değişerek öğretmen, birtakım bilgileri öğrencilere aktararak öğreten değil; öğrencilerin, kendi yaşantılarından ve ön bilgilerinden hareketle yeni bilgilere ulaşmalarını sağlayan kişi konumuna gelmiştir.

\section{Öğrenci Değerlendirilmesinde Mevcut Yöntemler}

Acat ve Ekinci (2005)'ye göre yapılandırmacı yaklaşım, çoklu zekâ anlayışını öngören, öğrenci merkezli eğitimin ilkeleri beraberinde, sonuç odaklı geleneksel ölçme ve değerlendirme teknikleri yerine, süreç odaklı yani "değişikliklere sürekli açık olan, ölçme ve değerlendirmeye ayrı bir önem veren çağdaş eğitim sistemleri bireyden bilgiyi ezberleyen değil; bilgiyi üreten, dünyayı yorumlayan, öğrenme yeteneklerini geliştiren, eleştirel düşünen, yaratıcı olan, problem çözebilen, üst düzey düşünme becerilerine sahip ve değişen koşullara uyum sağlayabilen bireyler yetiştirmeyi hedefleyen" yeni ölçme ve değerlendirme tekniklerini de getirmiştir. Geleneksel ölçme ve değerlendirme tekniklerini; çoktan seçmeli testler, doğru yanlış soruları, eşleştirme soruları, tamamlama (boşluk doldurma) soruları, kısa cevaplı yazılı yoklamalar, uzun cevaplı yazılı yoklamalar, soru-cevap, şeklinde toplamak mümkündür. Geleneksel ölçme ve değerlendirme teknikleriyle yapılan değerlendirmelerin ürüne yönelik olduğu, dönem sonunda gerçekleştirildiği ve ayrıca değerlendirmenin sadece öğretmen tarafindan yapıldığı görülmektedir.

Yeni ölçme ve değerlendirme teknikleri ise; performans değerlendirme, ürün seçki dosyası (portfolyo), tanılayıcı dallanmış ağaç, yapılandırılmış grid, kavram haritaları, kendi kendini değerlendirme, grup ve/veya akran değerlendirmesi, kelime ilişkilendirme, proje, drama, görüşme, yazılı raporlar, gösteri, poster şeklinde sıralanmaktadır. Yeni ölçme ve değerlendirme yöntemlerinin temel özelliklerine bakıldığında ise değerlendirme sürece bağlıdır ve değerlendiren taraf sadece öğretmen değildir. Öğrencilerde bu konuda aktiftirler. Dönem boyunca devam eder ve daha anlamlı olduğu görülmektedir (Şimşek, 2009, s. 587)

Adanalı (2008), yeni ölçme ve değerlendirme tekniklerinin uygulama aşamasına geçildiğinde, ilköğretim beşinci sınıf sosyal bilgiler dersinin ölçme ve değerlendirme sürecinde hangi alternatif ölçme ve değerlendirme etkinliklerinin nasıl kullanıldığı, bu değerlendirme etkinliklerinin etkileri ve bu konuda karşılaşılan sorunların neler olduğu ile öğretmenlerin sorunları gidermek için başvurdukları etkinliklerin belirlenmesini amaçlayan bir çalışma yapmıştır. Araştırmanın bulgularına göre; beşinci sınıfta öğretim yapan öğretmenlerin \%44.9'u (92 kişi) alternatif ölçme ve değerlendirme yaklaşımları ile ilgili herhangi bir eğitim almamışlardır. Eğitim alan öğretmenler ise (\%55.1), aldıkları eğitimi yetersiz olarak nitelemişlerdir. Eğitim alan veya almayan öğretmenlerin; kılavuz kitaplarındaki açıklamalarla, arkadaşlarıyla tartışarak, alternatif ölçme ve değerlendirme etkinlikleri hakkındaki farklı kaynakları, internet bilgilerini inceleyerek ya da deneyip yaşayarak kendilerini bilgilendirdikleri belirtilmişstir. 


\section{Eğitim-Öğretimde Kılık Kıyafet}

Eğitim-öğretim dönemlerinde öğrenci niteliğine sahip bireylerin nasıl bir kıyafet ile öğrenim görecekleri, kanunlar kapsamında ele alınan ve uyum sağlama yükümlülüğü olan mevcut bir durumdur. Eğitim-öğretim döneminde öğrencilerin serbest kiyafet ile öğrenim görmesi uzun yıllardır tartışma konusu olmuştur. Türkiye'de ilköğretim öğrencilerinin okul kıyafetlerine yönelik yapılan ilk düzenleme 1981'den sonra siyah önlüğün mavi ile değiştirilmesidir. Daha sonraki dönemde yapılan yönetmelik değişikliğinde ise, ilköğretim okullarındaki kıyafetler, belirli kurallara uyulması şartıyla serbest bırakılmıştır. 27 Kasım 2012 tarihinde MEB'e bağlı okullarda öğrencilerin kılık ve kıyafetlerine dair yeni yönetmelik Bakanlar Kurulu kararı ile Resmi Gazete'de öğrencilerin yapılan işin özelliğine uygun kıyafet giymeleri dışında, kılık kıyafetin serbest olduğu yayımlanmıştır.

Üstün ve Çeğindir (2006), Türkiye'de İlköğretim çağı çocukları ve annelerinin okul önlük ve formalarının ele alındığı bir araştırma yapmıştır. Araştırma bulgularına göre; genel olarak, çocukların \%65'inin forma modellerinden memnun olduğu tespit edilmiştir. Erkek çocukların forma modellerinden memnuniyeti kızlara oranla daha fazladır. Forma çeşidine göre incelendiğinde önlük kullananların \%96'sının, özel forma kullananların \%34,3'ünün forma modelinden memnun olduğu belirlenmiştir. Forma çeşitlerine göre; önlük kullananların \% 51'i formalarının renginden memnun iken, özel forma kullananların \%37'si memnun görünmektedir. Çocukların \%67'sinin forma kalıplarından memnun olduğu ancak \%60'ının formalarının kullanım özelliklerinden memnun olmadıkları görülmektedir. Annelerin \%57'sinin çocuklarının okul forma modellerinden memnun oldukları, \% 49'unun forma kalıplarından memnun, \%44'ünün memnun olmadıkları saptanmıştır. Annelerin \%48'i çocuklarının forma renginden memnun, \%52'si memnun değildir. Annelerin \%73'ü çocuk formalarının kullanım özelliklerinden memnun olmadığı tespit edilmiştir.

\section{Öğrencinin Okula Devam Etme Zorunluluğu}

Eğitimin en temel amac1, kendine yetebilen, üreten ve toplumda bağımsız şekilde işlevde bulunabilen bireyler yetiştirmektir. $\mathrm{Bu}$ işlevleri yerine getirebilmek öğrenilen beceri ve davranışlarla mümkün olabilmektedir. Bu becerileri öğrenmek planlanmış ve düzenlenmiş yaşantılar yoluyla gerçekleştirilmektedir. Bu sebeple öğrencilerin bu yaşantılara ayak uydurması beklenmektedir. Öğrencinin belli bir yerde, kurallar çerçevesinde eğitim alması için okul adı verilen kurumlar işe koşulmuştur. Öğrenciden beklenen ise belli zamanlarda verilen öğretimi alabilmesi için bu kurumlara devamlılığın sağlanmasıdır. Bu durum MEB tarafından güvence altına alınmalıdır. MEB'in devam durumu ile ilgili yönetmeliğinde velilerin ilköğretim çağındaki öğrencilerin devam etme durumunda sorumluluğu olduğu belirtilmektedir (İlköğretim Kurumları Yönetmeliği md. 18, 2014). Ancak diğer bir nokta, öğrencilerin çok uzun bir süreyi bulmadıkça devamsızlıktan kalmadığı hükmünün yayınlanmasıdır. Uzun süreden kasit ise 4-5 aydan fazla süredir hiç gelmeyen öğrenci kastedilmektedir. Ayrıca öğrenci 14 yaşına geldiğinde okula gelme zorunluluğu da ortadan kalkmaktadır (MEB, 2014). 


\section{Yaş İtibariyle 5. Sınıf Öğrencilerinin Hazırbulunuşluluğu}

Hazırbulunuşluluk; bir öğrenme durumundan hemen önce, bireyin sahip olduğu ve öğrenme ortamına getirdiği bütün bilişsel, duyuşsal ve psiko-motor özelliklere ait donanımıdır. $\mathrm{Bu}$ donanım öğrencilerin yeni konuyu öğrenmesini ve anlamlandırmasını etkiler.

Gelişim, döllenme ile başlar ve yaşam boyu devam eder. Bu süreçte tüm bireyler için geçerli olan bazı evrensel süreçler bulunmaktadır. 5. sınıftaki bireylerin gelişim evreleri incelendiğinde, geçiş döneminde oldukları görülmektedir. Bebeklik ve okul öncesi dönemde olduğu gibi bu dönemde de çeşitli değişiklikler, gelişmeler olur. Temel bazı zihinsel beceriler geliştirilebilir. Öyle ki, temel matematik ve fizik prensipleri öğrenebilecek düzeye ulaşır. Daha önceki dönemlerde, birinin düşüncesini başkalarından ayıramazken, yavaş yavaş bu ayrımın farkına varır. Hiç görmediği yerler ve hiç karşılaşmadığ 1 insanlar hakkında düşünceler geliştirir ve fikirler üretebilir. Yıldızları, gezegenleri, güneş sistemini, cenneti vb. merak eder, bu konularda bolca sorular sorar, fikirler üretir. Yine bu dönemde hayal kurma, canlandırma ve espri yetenekleri gelişir.

Piaget, 7-11 yaş grubundaki çocukların bu dönemine "somut işlemler" dönemi olarak adlandırır. Piaget' e göre bu dönemdeki çocuklar yeni bir dizi kural geliştirirler. Nesneleri renk, uzunluk, madde gibi farklılıklara göre sınıflandırırlar. Belirli nesneler arasındaki değişmeyen ilişkileri, nesneleri görmeden mantık yürütme yoluyla kavrayabilirler. Dokuz yaşlarına kadar çocukların çoğu sınıflar arasındaki ilişkileri anlamakta zorluk çekerler. Piaget burada şunu göstermiştir: Çocuklar; güller, laleler ve diğer çiçeklerin hepsini çiçekler sınıfına girdiklerini kabul etmekte ancak tüm çiçeklerin öldüklerini bilmelerine karşın, güllerin ya da lalelerin oldukları gibi kaldıklarını öne sürmektedirler; çünkü bu yaşlardaki çocuklar için alt sınıflar hala bir ölçüde ayrı bir varlığa sahiptir. Bu dönemlerde çocuklarda sağ sol kavramı gelişir, kendi vücudundaki sağını solunu gösterebildiği gibi başkası üzerindeki sağ1 solu gösterebilir. Ayrıca daha önceki yaşlarda gelişmemiş bazı kavramların geliştiği görülür. Şekil, boyut, uzaklık, sayı ve zaman kavramları gelişir (Bacanl1, 2011).

\section{Okula Başlama Yaşı ile İlgili Kararlar}

Dünya genelindeki uygulamalara bakıldığında; temel eğitim sürecini tek bir aşamada düzenlemek yerine, öğrencilerin yaş grupları ve fiziksel özellikleri temelinde bir kademelendirmenin tercih edildiği görülmektedir. Bu kapsamda öğrencilerin yaş grupları ve bireysel farklılıklarını dikkate almayan sekiz yıllık kesintisiz eğitimle Türkiye'nin genç nüfusunu, bilgi toplumunun gerektirdiği bilgi ve becerilerle donatmanın mümkün olmadığından hareketle eğitim sisteminde yeni bir yapılanmaya gidilmiştir.

6287 sayılı İlköğretim ve Eğitim Kanunu ile Bazı Kanunlarda Değişiklik Yapılmasına Dair Kanun ile zorunlu eğitim süresinin sekiz yıldan 12 yıla çıkarılmış ve bazı yeni uygulamaları gelmiştir, yeni uygulamaların daha etkili ve verimli bir şekilde yürütülmesini sağlamak amacıyla söz konusu kanunla getirilen düzenlemelerle ilgili 
olarak yapılan uygulamalardan bazıları şöyledir:

Zorunlu eğitim 4 y1l ilkokul, 4 yıl ortaokul ve 4 yıl da lise eğitimini kapsar, öğrencilerin öğrenim gördüğü birinci 4 yılın $(1,2,3$, 4. sinıflar) ilkokul, ikinci 4 yılın $(5,6,7,8$. sinıflar) ortaokul ve üçüncü 4 yılın $(9,10,11,12$. sinıflar) ise lise şeklinde isimlendirilir.

60-66 ay arasındaki çocukların ise velisinin yazılı isteği ile gelişim yönünden hazır olduğu anlaşılanların ilkokula devamları sağlanacaktır ve diğer öğrenciler ise okul öncesi eğitime yönlendirilecektir. Ayrıca okul öncesi eğitimde 48-60 ay arası çocuklar için 2013 y1lı sonuna kadar belirlenmiş olan yüzde 100 okullaşma hedefi devam edecektir.

Okul öncesi eğitim için 30 Eylül 2012 tarihi itibariyle 37-66 ay arasındaki çocukların anaokulunda veya uygulama sınıflarında, 48-66 ay arasındaki çocukların ise ana sınıflarında eğitim almaları sağlanacaktır (MEB, 2012).

Günümüzde dünya ülkelerinde okula başlama yaşı ve özellikleri değişiklik göstermektedir. Almanya'da zorunlu okula başlama yaşı 6'dır. Bu yaştan önceki eğitimde gönüllülük esastır. İngiltere'de zorunlu okula başlama yaşı 5 'tir. Avusturya'da da okula başlama yaşı 6'dır. Resmi akademik takvim eylül ayının başında başlar, haziran ayının sonuna doğru sonlanır. Danimarka'da okula başlama yaşı 7'dir. Finlandiya'da da okula başlama yaşı 7'dir. Japonya'da geleneksel okula başlama yaşı 6'dır. Dünya genelindeki uygulamalara bakıldığında, ortalama eğitim süresi 11-12 yıl veya daha üzerindedir. Türkiye'de ise toplam nüfusun ortalama eğitim süresi 6-6,1 y1l civarındadır. Başka bir ifadeyle, gelişmiş dünya ülkeleri ile Türkiye'nin eğitim süresi arasında tam yarı yarıya bir fark söz konusudur. Avrupa Birliği ülkeleri 2020 yılına kadar nüfuslarının en az \%90'ını lise mezunu yapmak üzere hedeflerini revize etmişlerdir (Dere \& Poyraz, 2001).

\section{Yöntem}

\section{Araştırma Modeli}

Araştırmada, nitel araştırma yöntemlerinden yapılandırılmış görüşme tekniği kullanılmıştır. $\mathrm{Bu}$ çalışmanın deseni, durum çalışmasıdır. Durum çalışmalarında, araştırmacı tarafindan bir veya daha fazla durum ayrıntılı olarak, derinlemesine ortaya koyulmaktadır (Christensen, Johnson \& Truner, 2015, s.416).

\section{Çalışma Grubu}

Araştırmacılar tarafından uzman görüşüne sunulduktan sonra son şekli verilen sorular iki devlet okulunda görev yapan çeşitli branşlardan toplam 25 öğretmene yöneltilmiş ve görüşleri alınmıştır.

\section{Veri Toplama Aracı ve Verilerin Analizi}

Araştırma başlangıcında alanyazın incelenmiş, inceleme sonucunda amacına uygun olarak soru taslağı hazırlanmıştır. Sonraki aşamada soru taslağı, anlaşılabilirlik açısından Türkçe öğretmenlerine ve alanında uzman 17 öğretim üyesine sunulmuştur. 
Taslakta yer alan 11 sorudan 5'i dışında kalanlar, konuyu kapsamadıkları ve anlaşılabilirlikten uzak oluşları gerekçesiyle çıkarılmış, böylece sorular son şeklini almıştır.

Öğretmenlerle yapılan görüşme sonucunda toplanan veriler benzer görüşler çerçevesinde gruplandırılmıştır. Öğretmenler katılımc1 K1, K2, K3, K4,....,K23, K24 ve K25 şeklinde kodlanmıştır. Çalışma veriler, betimsel analiz yapılarak analiz edilmiştir. Temalar, seçilen konu başlıklarından oluşturulmuş ve alınan görüşler, bu temalar altında uygun yerlere konulmuştur. Betimsel analiz sırasında, araştırmanın güvenirliği, iki farklı araştırmacının alınan verileri temalar altına kodlaması sonuncunda aynı sonuca ulaşılmasıyla sağlanmıştır. Katılımcıların çoğunlukta olduğu görüşler, katılan kişi sayısı ile gösterilmiş ( $5 \mathrm{~K}$ gibi), örnek olarak yazılan görüş ise görüşü belirtilen kişinin kodu ile belirtilmiştir (K5 gibi).

\section{Bulgular}

Açık uçlu anket sonucunda ortaya çıkan bulgular aşağıda maddeler halinde özetlenmiştir.

Öğrenci merkezli yaklaşımların öğrenci başarısına etkili olup olmadığı konusunda bulgular:

Araştırma bulgularına göre, öğretmenlerin çoğunlukla, öğrenci merkezli yaklaşımların öğrenci başarısına etkisi konusunda, bu yaklaşımların etkili olduğunu ancak öğretmenlerin yaklaşıma bakış açısı, öğretmenlerin bu konuda bilgisi ve öğrenci üzerine etkisinin göz ardı edilmemesi gerektiği görüşüne katılmakta oldukları bulunmuştur $(5 \mathrm{~K})$.

Öğretmenler ayrıca öğrenci merkezli yaklaşımın ancak öğrenci zeki ve başarılı olduğunda ve uygulama imkânlarına sahip olunduğunda etkili olduğunu belirtmektedirler (3K).

Öğretmenlerin büyük çoğunluğu ise öğrenci merkezli yaklaşımların öğrencileri akademik, kişilik ve sosyal gelişim açısından olumlu etkilediğini düşünmektedirler (5K). Bu konuya katılan bir öğretmen ise düşüncesini şöyle belirtmiştir:

'Öğrenci merkezli yaklaşımların, öğrencilerin akademik, sosyal ve kişilik gelişimi açısından bakıldığında olumlu etkisi olduğunu düşünüyorum. Şöyle ki yeni yaklaşımlar ögrrencileri bir bütün olarak ele almakta, her yönden gelişimini amaçlamaktadır.'(K23).

Öğretmenlerin bir kısmı ise geleneksel yöntemlerle yeni yaklaşımları karşılaştırarak, geleneksel yönteme göre öğrenci başarısında yeni yöntemlerin daha etkili olduğu fikrine katılmaktadırlar (5K).

Öğrencilerin değerlendirilmesinde mevcut yöntemlerin yeterliliği hakkındaki bulgular:

Araştırmaya ilişkin bulgulara göre öğretmenlerin büyük çoğunluğu öğrenci değerlendirmelerinde çeşitli yöntemlerin bulunduğunu, bu yöntemler beraber kullanılarak öğrencinin bütün olarak değerlendirilmesi gerektiğini söylemişler ve 
mevcut yöntemler ancak bu şekilde tam kullanılırsa yeterli olabileceği düşüncesinde birleşmişlerdir (9K). Araştıramaya katılan bir öğretmenin görüşleri şu şekildedir:

'Öğrenci değerlendirmesinde çeşitli yöntemler bulunmaktadır ve sadece bir yöntemle ögrenci değerlendirmesi yapılmamalıdır. Yöntemler çeşitli şekillerde beraber kullanılarak öğrenci bütün olarak görülerek değerlendirilmelidir.'(K25).

Öğretmenlerden bazıları zekânın çok boyutlu olduğunu bu yüzden öğrenci değerlendirmesinin de çok yönlü olması gerektiğini belirtmişlerdir. Ayrıca değerlendirme yapabilmek için öğrencinin ilgi ve yeteneklerinin tanınması gerektiği ancak sınıf mevcutlarının kalabalık olması nedeniyle bunun imkânsızlaşıp sonucunda da gerçekçi değerlendirme yapılamadığını söylemişlerdir (3K). Örneğin bu konuda ilgili bir öğretmen düşüncesini şöyle belirtmektedir:

'Zekâ çok boyutludur. Değerlendirme yapabilmek için öğrenciyi, onun ilgi ve yeteneklerini tanımak gereklidir fakat sınıf mevcutları çok kalabalık olduğu için ögrencileri tanıyabilmek imkânsızlaşmakta ve bunun sonucunda da değerlendirmeler gerçekçilikten uzak kalmaktadır'(K21).

Serbest kıyafet uygulamasının öğrencilerin kişilik ve sosyal yönden gelişimine, akademik başarısına etkisi hakkında bulgular:

Araştırma bulgularına göre, öğretmenlerin serbest kıyafet uygulamasının öğrencilerin akademik başarısına, kişilik ve sosyal yönden gelişimine etkisi konusunda, bu uygulamaların öğrenciler üzerinde etkilerinin göz ardı edilemez olduğunu fakat serbest kıyafet uygulamasının ekonomik yönden düşük gelirli ailelerin çocuklarını olumsuz etkilediği ve akademik yönden öğrenciye bir katk1 sağlamadığ1 görüşünde çoğunlukla birleşmişlerdir (9K). Örneğin bir öğretmenin konuyla ilgili görüşleri şöyledir:

'Serbest klyafet uygulaması ekonomik yönden düşük gelirli olan ailelerin çocuklarını olumsuz etkiler. Ayrıca akademik başarı yönünden de öğrenciye katkısının olacă̆ını düşünmüyorum.' (K5).

$\mathrm{Bu}$ görüşe benzer bir ifade ise öğrencilerin serbest kıyafet uygulaması ile kendi ideolojilerini okul ortamında rahatça yansıtmasının okul ortamını olumsuz etkileyecek olması konusundaki görüşlerdir (4K).

Konuya ilişkin olarak serbest kıyafet uygulamasının öğrencileri olumlu etkilemediği ve okul formasının daha uygun olduğu $(6 \mathrm{~K})$ düşüncelerinin aksine birçok öğretmen, serbest kıyafet uygulamasının iyi bir uygulama olduğunu, öğrencinin kendini daha rahat hissedip, serbestliğin hür düşünce ve fikirlerin ortaya çıkmasında etkili olacağını, çünkü baskı ve zorbalığın öğrenciyi olumsuz etkileyeceğini düşünmektedir. Ayrıca öğretmenler serbest kıyafeti uygulamasının kendileri içinde uygulanmasının iyi olacağını düşünmektedirler (4K).

$>$ Öğrencilerin derse devam durumu ile ilgili öğretmen yaptırımına ilişkin hakkındaki bulgular:

Araştırma bulgularına göre, öğretmenler öğrencilerin derse devam durumu ile ilgili öğretmen yaptırımının olmaması konusunda, eğitim öğretim açısından devam 
durumunun önemli bir konu olduğu ve öğretmenlerden çok idareyle ilgili bir durum olduğundan idare tarafindan takip edilmesi gerektiği görüşünde çoğunlukla birleşmişlerdir (4K). Ayrıca, araştırmaya katılan beş öğretmen, öğrencilerin derse devam durumu ile ilgili öğretmen yaptırımının olması gerektiğini ve öğretmenlerin öğrenciyi takip edip ve bu konu hakkında veli ile irtibata geçtiği takdirde okula devamın sağlanabileceği düşüncesini savunurken, iki öğretmen ise öğretmen yaptırımının çok önemli olmadığını, öğretmenlerin öğrenciler üzerinde hiçbir zorlayıcı etkisi olmaması gerektiği düşüncesini savunmuştur $(2 \mathrm{~K})$.

Derse devam konusunda öğretmenlerin yaptırımının olmaması sonucunda ortaya çıkan sorunlara ilişkin öğretmen görüşlerine bakıldığında ise, öğretmen yaptırımının olmamasının öğrencilerin kendini daha özgür hissetmesine, öğretmenin kısıtlanmasına neden olduğu ve ayrıca öğrencilerin sınıfta kalmasını engellediğinden öğrencilerin okulu önemsiz görmeye başladığını (4K); öğrencinin ders seçmesini ve sevmediği derslerden kaçması gibi olumsuz sonuçları doğurmakta olduğunu ve böylece öğrenci kontrolünün zorlaşmasına neden olduğunu (3K); öğrencilerde ciddiyetsizliğe yol açtığını ve bu durumun ise öğrenci başarısını olumsuz etkilediği düşüncesini savunmuşlardır (3K). Bu konuda bir öğretmen düşüncesini şöyle ifade etmiştir:

'Disiplinsiz eğitim-ögretim öğrencide ciddiyetsizliğe yol açmaktadır. Bazı ögrenci velileri de bu durumu önemsememekte ve tüm bunların sonucunda ögrenci başarısı olumsuz etkilenmektedir.'(K11).

5. sınıf öğrencilerinin hazırbulunuşluluğu açısından branş öğretmenlerinin derslere girmesi konusunda bulgular:

Araştırma bulgularına göre, 5. sınıf öğrencilerinin hazırbulunuşluluğu açısından branş öğretmenlerinin derse girme konusunu nasıl değerlendiriyorsunuz sorusuna, 'uygun buluyorum, ilerleyen dönemlerde daha iyi olacağını düşünüyorum' görüşüne öğretmenlerin çoğu katılmaktadır (15K). Ayrıca bu öğretmenlerden çoğu, yeni sistemin daha ileriki zamanlarda oturacağını ve var olan sorunların zamanla aşılacağını belirtmektedir. Bu konuda bir öğretmen şöyle belirtmektedir:

'5. sinıf ögrrencilerinin yaşlart itibariyle somut işlemler döneminin sonunda olması öğrencilerin soyut işlemler dönemine geçmeye başladı̆̆ aşamadır. Branş ögretmenlerinin bu dönemde derslere girmesini uygun buluyorum. Geçiş döneminde hem ögrrenci hem de ögrretmen açısından sıkıntılı oldu fakat zamanla aşılır.'(K8).

Ancak öğretmenlerden bir kısmı ise öğrencilerin hazırbulunuşlukları açısından branş öğretmenlerinin 5. sınıf derslerine girmesini uygun bulmadıklarını belirtmektedir (4K). Geçiş dönemi açısından öğrencileri yeterli görmeyen bir branş öğretmeni, bu konuda şöyle belirtmektedir:

'Hazırbulunuşluluklarının yeterli olmadiğını düşünüyorum. O yaş çocukları bir geçiş dönemi içindeler ve her öğrencinin gelişimi aynı olmadiğı için branş ögretmenlerinin derse girmesi konusunu uygun bulmuyorum.' (K20)

Bir grup öğretmen ise branş öğretmenlerinin öğrenci seviyesine inebildiği sürece uygun olduğunu düşünmektedirler (3K). 
$>$ Okula başlama yaşının düşürülmesinin öğrencilerin okul başarısına ve psikolojik durumlarına etkisi hakkındaki bulgular:

4+4+4'lük eğitim sistemine geçmeden önce öğrenciler 1. sınıfa 72. aylarını doldurduklarında başlamaktaydılar. Yeni sistemde ise 60-66 aylık grubun veli isteğine bağlı olarak okula kayıtları yapılmaktadır. Yeni sisteme geçilmesiyle de 60 aylık çocuklarla eski sistemde olduğu gibi en küçügü 72 ayını doldurmuş çocuklar aynı sınıf ortamında eğitim görmektedirler. Araştırma bulgularına göre, katılımcıların büyük bir çoğunluğu, akademik başarısı, kişilik, sosyal ve fizyolojik gelişimleri gibi nedenlerle öğrenciler bir bütün olarak ele alındığında, okula erken yaşta başlamanın etkilerini olumsuz bulmakta olduklarını belirtmişlerdir (18K). Bu konudaki görüşlerini bir öğretmen şöyle belirtmiştir:

'Gerekli bir uygulama değildi. Özellikle 60-66 aylık grubun veli isteğine bağll kaydedilmesi çok sakıncalı. Veli bilinçsizce çocuğu erken yaşta kaydettiriyor ve sıkıntıyı çocuk çekiyor. Küçük çocuk diğerlerinin yanında hem eziliyor hem de başarısız oluyor. Çocuk kendini ifade etmekte güçlük çekiyor, günlük ihtiyaçlarını karşılarken bile zorluk çekiyor.'(K13).

Bir grup öğretmen uygulamayı okulların ve eğitim programlarının uygun hale getirildiği zaman küçük yaşta okula başlamanın olumlu olacağını düşünmektedirler (3K). Aynı şekilde, eğitimin erken yaşta başlaması gerektiğini ve öğrencilerin psikolojileri bu yaşta bu duruma hazır olduğunu belirtmektedirler. Öğretmenlere göre bu durum öğrencilerin okul başarılarına da olumlu etki yapmaktadır (4K).

\section{Sonuç ve Tartışma}

Dünya hızla küreselleşmekte ve beraberinde pek çok yenilik getirmektedir. $\mathrm{Bu}$ yenilikler ve değişim tüm bireyleri dolayısıyla da eğitimi etkilemektedir. Eğitim insan yetiştirme ile doğrudan ilişkili olduğundan bireylerin değişen dünyaya daha iyi ayak uydurabilmesi ve istenilen nitelikleri karşılayabilmeleri için eğitim uygulamalarına bazı yenilikler getirilmiştir. $\mathrm{Bu}$ yeniliklerden biri öğrenci merkezli yaklaşımlardır. Konu hakkında görüşülen öğretmenlerin birleştikleri nokta, yapılandırmacı yaklaşım ile öğrenci merkezli öğretim anlayışı temele alınarak, öğrencilere bilgi aktarımı yerine, öğrencilerin bilgiyi zihinsel ya da sosyal olarak yapılandırmasının amaçlandığıdır. Ayrıca, uygulamanın öğrenciler üzerinde olumlu etkileri olduğu ancak öğrenci üzerinde öğretmen etkisinin göz ardı edilmemesi gerektiği vurgulanmaktadır. Mevcut yöntemler hakkında öğretmenlerin büyük çoğunluğu, geleneksel yöntemleri, öğrencileri tek yönlü olarak ele alması, yöntemlerin tüm dersler için genel olması, sonuç odaklı olması ve değerlendirmenin sınıfla sınırlı kalması gibi nedenlerden dolayı yetersiz bulmaktadır. Öğretmenler değerlendirmenin nasıl olması gerektiği hakkındaki düşüncelerini; öğrencilerin ilgi ve yetenekleri göz önünde bulundurularak öğrencinin bir bütün olarak ele alınması, değerlendirmenin sınıfın dışına da taşınması, süreç odaklı olması ve her dersin kendi sistematiğine göre bir değerlendirme yöntemi içermesi şeklinde belirtmişlerdir. Öğretmenlerin bu görüşlerine bakıldığında yeni değerlendirme metotlarının özellikleriyle uyuşma sağlandığı görülmektedir. 
Eğitimin temel gayesi çocukların mutluluğu, özerkliği ve onların bağımsız iş yapabilme kapasitesini geliştirmektir. Bu doğrultuda eğitim-öğretimde kılık kıyafet düzenlemesine ilişkin olarak eğitim sistemi gittikçe tektipçilikten uzaklaşmakta ve daha fazla toplumsal taleplere duyarlı hale gelmektedir. Serbest kıyafet uygulaması hakkında olumsuz düşünen öğretmenlerin, bu durumun ekonomik farklılığ zengin-fakir ayrımını tetikleyeceği ve sınıf farklılığının oluşacağı yönünde kaygılı oldukları fark edilmektedir. Bunların yanı sıra dikkatin akademik süreçten uzaklaşacağını ve bireylerin ideolojilerini okul ortamına daha rahat yansıtacağına dair düşüncelerini eklemişlerdir. Bir grup öğretmen ise ekonomik farklılığı ortaya çıkarmada serbest kıyafet uygulamasının ön koşul olmadığını, öğrencilerin bunu ayakkabılarıyla çantalarıyla da vs. ortaya koyabileceklerini savunmaktadırlar. Serbest kiyafet uygulamasıyla daha özgür, kendine güvenen bireylerin yetişeceğini ve kıyafetle başarının ölçülemeyeceğini belirtmektedirler. Aynı şekilde Üstün ve Çeğindir (2006)'in yaptığı çalışma bulgularına göre de annelerin çoğunluğu forma kullanımından memnun olmadıklarını belirtmişlerdir.

Öğrencinin okula devam etme zorunluluğu konusunda ise, öğretmenler, öğrencilerin derse devam durumu ile ilgili öğretmen yaptırımının kesinlikle olması gerektiğini belirtmişlerdir. Yaptırımın olmaması durumunda öğrencilerin sevmedikleri derslerden kaçması gibi olumsuz durumlarla karşılaşıldığını bunun da başarıyı olumsuz etkilediği dile getirilen bir başka noktadır. 5. sınıf öğrencilerinin hazırbulunuşluluğu açısından branş öğretmenlerinin derse girmesini uygun bulmayan öğretmenlerin birleştikleri nokta, bu dönem bireylerinin bir geçiş döneminde olmaları ve bu evredeki çocukların yeni bilgileri uyumsamaları için sınıf öğretmenlerinin en iyi rehber konumunda olmasıdır. Çocuğu hazırbulunuşluk açısından iyi tanıyan sınıf öğretmenlerdir çünkü çocuğun karşısına anne babasından sonra ilk gelen, bağlandığı ilk kişidir ve genellikle aralarında güvenli bağlanma oluşmaktadır. Ayrıca ilkokulda törel gelişim açısından öz-düzenleme bu yaşlarda tam kazanılmadığı için yetişkinin kılavuz olması ve onları denetlemesi önemlidir. Bu denetlemenin olması için de çocukla öğretmen arasında güçlü etkileşimin olması gerekmektedir. Bu konuyu olumlu karşılayan ve çoğunluğu oluşturan öğretmeler ise gerekli çalışmaların yapılmasıyla ileriki yıllarda bu uygulamanın daha iyi olacağını düşünerek hazırbulunuşluluk açısından bir sorun görmemektedirler. Bir başka yenilik ise tartışmalı bir konu olan okula başlama yaşının düşürülmesidir. Araştırmaya katılan öğretmenlerin çoğu, okula başlama yaşının düşürülmesinin öğrencilerin okul başarısına ve psikolojik durumlarına etkisinin olumsuz olduğunu ancak okulların ve eğitim programlarının uygun hale getirildiği zaman küçük yaşta okula başlamanın olumlu olacağını düşünmektedirler. Her bakış açısı, her düşünce farklıdır ve tabi ki farklı cevaplar vardır ancak atalarımızın da dediği gibi "ağaç yaşken eğilir" atasözüne uygun olması yönüyle düzenleme avantajlı görünmekte, ileriye dönük bir ümit ışı̆̆ı oluşturmaktadır. 


\section{Öneriler}

Araştırma sonuçlarından ortaya çıkarılan öneriler şunlardır:

- Öğrenci merkezli yaklaşımların öğretmenlere benimsetilmesi ve bu konuda bilgilerinin artırılması için öğretmenlere seminerler düzenlenebilir.

- Öğrenci değerlendirmesinde öğretmenlerin çoğunun kalabalık sınıflardan şikâyetçi olduğu göz önüne alınırsa, sınıf mevcutlarına daha etkili öğrenmenin gerçekleşmesi amacıyla sinırlandırma getirilebilir.

- Öğrencilerin serbest kıyafetle okula gelebilmesi konusunda nihai karar sadece okul idarecilerine bırakılmayarak okul öğretmenlerinin de görüşleri ve okul çevresinin sosyoekonomik düzeyi dikkate alınabilir.

- Derse devam konusunda öğrencilerin bu özgürlüğü suiistimal etmemesi için gerekli önemler alınabilir.

- $\mathrm{Bu}$ çalışma, daha geniş bir kitleye uygulandığında eğitim sisteminin karar vericilerine yol gösterici olabilir. 


\section{Kaynakça}

Adanalı, K. (2008). Sosyal bilgiler eğitiminin alternatif değerlendirme etkinlikleri açısından değerlendirilmesi (Yayımlanmamış yüksek lisans tezi). Çukurova Üniversitesi, Adana.

Bacanl, H. (2011). Eğitim psikolojisi. Ankara: Pegem Akademi.

Christensen, L. B., Johnson, R. B. \& Turner, L. A. (2015). Araştırma yöntemleri, desen ve analiz. (A. Aypay, Çev.). Ankara: Anı Yayıncılık (2014).

Çınar, O., Teyfur, E. \& Teyfur, M. (2006). İlköğretim okulu öğretmen ve yöneticilerinin yapılandırmacı eğitim yaklaşımı ve programı hakkındaki görüşleri. İnönü Üniversitesi Eğitim Fakültesi Dergisi, 7(11), 47-64.

Dere, H. \& Poyraz, H. (2001). Okul öncesi eğitimin ilke ve yöntemleri. Ankara: Anı Yayınları.

Erdem, E. (2001). “Program geliştirmede yapılandırmacılık yaklaşımı (Yayımlanmamış yüksek lisans tezi). Hacettepe Üniversitesi, Ankara.

Ergün, M. (2013). Medreseden mektebe Osmanlı eğitim sistemindeki değişme. [online] http://www.egitim.aku.edu.tr/ergun3.htm adresinden alınmıştır.

Ertürk, S. (1984). Eğitimde program geliştirme (5. Baskı). Ankara: Yelkentepe Yayınlar1.

Fidan, N. (1996). Eğitim psikolojisi: Okulda öğrenme ve ögretme. Ankara: Alkım Yayınevi.

Milli Eğitim Bakanlı̆̆1 -MEB-. (2005). İlköğretim 1-5. sınıf programları tanıtım el kitabı. Ankara: Milli Eğitim Müdürlüğü Basımevi.

MEB (2012). Serbest k1yafet uygulaması yönetmeliği. [online] http://www.meb.gov.tr/mevzuat/ adresinden alınmıştır.

MEB (2014). İlköğretim kurumları yönetmeliği. [online] http://www.meb.gov.tr/mevzuat/ adresinden alınmıştır.

Özden, Y. (2000). Öğrenme ve ögretme (4. Baskı). Ankara: PegemA Yayıncılık.

Özden, Y. (2005). Ĕgitimde yeni değerler (eğitimde dönüşüm) (6. Bask1). Ankara: PegemA Yayıncilik.

Resmi Gazete (2012). İlköğretim ve Eğitim Kanunu İle Bazı Kanunlarda Değişiklik Yapılmasina Dair Kanun. [online] http://www.resmigazete.gov.tr /eskiler/2012/04/20120411-8.html adresinden alınmıştır.

Şimşek, N. (2009). Sosyal bilgiler öğretimi. M. Safran (Ed.) içinde, Sosyal bilgilerde ölçme değerlendirme (ss. 571-624). Ankara: Pegem Akademi Yayınları.

Titiz, O. (2005). Yeni ögretim sistemi. İstanbul: Zambak Yayınları.

Üstün, G. \& Çeğindir, N.Y. (2006). İlköğretim çağı çocukları ve annelerinin okul, önlük ve formalarının konforundan memnuniyet durumlarının incelenmesi. Hacettepe Üniversitesi Sosyolojik Araştırmalar e-Dergisi, 5, 1-13. 